\title{
PENINGKATAN PEMASARAN PRODUK MEBEL MELALUI IMPLEMENTASI TEKNIK PEMASARAN ON LINE
}

\author{
Nugraha Arif Karyanta1,2), Susantiningrum 1)3), Edwi Mahadjoeno, ${ }^{1,4)}$ \\ 1) Pusat Pengembangan Kewirausahaan LPPM \\ Universitas Sebelas Maret \\ 2) Fakultas Kedokteran Universitas Sebelas Maret \\ 3) Fakultas Keguruan dan Ilmu Pendidikan Universitas \\ Sebelas Maret \\ 4) Fakultas Matematika dan IPA Universitas Sebelas Maret \\ Email: optimissaja@gmail.com
}

\begin{abstract}
ABSTRAK
Industri mebel dan kerajinan merupakan industri yang cukup banyak menyerap tenaga kerja. Industri ini masuk ke dalam 10 industri unggulan yang menyumbang kinerja ekspor nasional. CV. Jembatan Lintas Benua merupakan salah satu UKM yang berkecimpung di dunia mebel. CV. Jembatan Lintas Benua bertempat di Serenan, Sukoharjo. Mebel yang diproduksi merupakan mebel kayu dengan gaya modern minimalis. Saat ini, pemasaran produk-produk mebel telah mengalami kemajuan hingga ekspor ke luar negeri. Untuk mendukung pemasarannya, CV. Jembatan Lintas Benua telah memiliki website yang dapat digunakan untuk melakukan pemasaran secara online. Akan tetapi, website tersebut belum dikelola secara optimal. Metode pemecahan masalah yang diterapkan kepada mitra antara lain; pelatihan inclass yang meliputi pelatihan kewirausahaan; pelatihan manajemen keuangan dan pelatihan manajemen pemasaran. Selain itu diberikan pula teknologi tepat guna berupa website serta seperangkat PC computer yang akan dilaksanakan dalam jangka waktu dua tahun. Output kegiatan IbPU ini diharapkan mampu meningkatkan kualitas SDM dan produk mebel kedua mitra serta meningkatkan jumlah ekspor pada skala yang lebih besar.
\end{abstract}

Kata kunci : mebel, ekspor, Serenan.

\section{ABSTRACT}

Furniture and craft industry is an industry that absorb many labor. This industry goes into 10 leading industries that contributes the national export performance. $C V$. Jembatan Lintas Benua is one of UKM which engaged in the world of furniture. CV. Jembatan Lintas Benua is located in Serenan, Sukoharjo. The produced furniture is wooden furniture with modern minimalist style. Currently, marketing of furniture products has progressed to export to overseas. To support marketing, CV. Jembatan Lintas Benua has a website that can be used to perform online marketing. But, the website has not been managed optimally. The method offered to the partners are inclass training and giving a website and computer. 
Inclass training includes entrepreneurship, financial management, and marketing management. Besides, it is given a website and a computer that will be held within a period of two years. It is expected that the activities of IbPU able to improve the quality of human resources, to increase the two partners's furniture products, and to increase the amount of exports on a larger scale.

Keywords : furniture, export, Serenan.

\section{PENDAHULUAN}

Kegiatan IbPU merupakan kegiatan pengabdian yang bertujuan untuk memberikan pendampingan usaha kepusaha industri mitra terpilih. Perbedaan dengan jenis pengabdian lainnya adalah pada kegiatan ini, industri mitra juga berkontribusi aktif dalam hal pendanaan selama kegiatan berlangsung.

Indonesia merupakan negara ke-2 yang memiliki jumlah hutan terluas di Dunia setelah Brazil. Hutan-hutan ini menghasilkan berbagai jenis kayu yang dapat dimanfaatkan untuk pembuatan perabot rumah tangga seperti meja, kursi, dan lemari (Tjoa, 2013). Industri mebel dan kerajinan merupakan industri yang cukup banyak menyerap tenaga kerja. Industri ini masuk ke dalam 10 industri unggulan yang menyumbang kinerja ekspor nasional. Mebel memiliki pangsa pasar yang cukup besar, baik pasar lokal maupun ekspor. Di Indonesia, Jawa Tengah adalah propinsi dengan pangsa pasar mebel sebesar 31-35\% terhadap total ekspor nasional. Hal ini menjadikan Jawa Tengah sebagai produsen mebel terbesar di Indonesia. Industri mebel yang dimiliki Indonesia secara kualitas mampu bersaing dengan industri mebel negara lain (Suseno, 2013).

Mebel atau furniture adalah perlengkapan rumah yang mencakup semua barang seperti kursi, meja, dan lemari. Mebel berasal dari kata movable, yang artinya bias bergerak. Pada zaman dahulu meja kursi dan lemari relative mudah digerakkan dari batu besar, tembok, dan atap. Sedangkan kata furniture berasal dari bahasa Prancis fourniture (1520-30 Masehi). Fourniture mempunyai asal kata fournir yang artinya furnish atau perabot rumah atau ruangan. Walaupun mebel dan furniture punya arti yang beda, tetapi yang ditunjuk sama yaitu meja, kursi, lemari, dan seterusnya.

CV. Jembatan Lintas Benua merupakan salah satu UKM yang berkecimpung di dunia mebel. CV. Jembatan Lintas Benua bertempat di Serenan, Sukoharjo. Mebel yang diproduksi merupakan mebel kayu dengan gaya modern minimalis. Pengerjaannya juga masih dilakukan secara konvensional dengan alat-alat TTG sederhana.

Saat ini, pemasaran produkproduk mebel telah mengalami kemajuan hingga ekspor keluar negeri yang dilakukan dengan bergabung dengan rekan 
perusahaan eksportir yang sudah eksis. Untuk mendukung pemasarannya, CV. Jembatan Lintas Benua telah memiliki website yang dapat digunakan untuk melakukan pemasaran secara online. Akan tetapi, website tersebut terkesan mati karena belum dikelola secara optimal.

Penjualan produk mebel khususnya mebel untuk ekspor menunjukkan angka yang fluktuatif setiap tahunnya, dengan trend yang cenderung menurun. Hal ini diakibatkan mahalnya harga bahan baku kayu dan rendahnya mutu bahan baku yang diakibatkan pengusaha kecil dan menengah mengalami kesulitan akses terhadap bahan baku dengan harga dan kualitas terbaik. Menurut Direktur Industri Hasil Hutan dan Perkebunan Kementerian Perindustrian (Kemenperin), Aryan Wargadalam pertumbuhan industri furniture hingga akhir tahun 2012 mencapai 10\% dibandingkan tahun 2011 (Neraca, 2016).

Menurut Road Map

Revitalisasi Industri Kehutanan Indonesia (2007), permasalahan yang dihadapi industri permebelan dan kerajinan meliputi kurangnya bahan baku, negative brand image akibat pembalakan liar, rendahnya kualitas produk Indonesia dibanding produk dari negara lainnya, lebih mahalnya harga produk Indonesia dibanding pesaing dan lebih disukainya produk-produk bersertifikat. Oleh karena itu, hendaknya industri mebel perlu membangun dan menggunakan sumber-sumber pasokan bahan baku alternatif dan menerapkan strategi usaha melalui penciptaan produk yang responsive terhadap permintaan pasar, khususnya pengembangan produk yang unik dan berdesain etnik. Selain itu, industri mebel juga perlu melakukan perbaikan teknologi agar diperoleh produkproduk yang berkualitas. Namun demikian, angka penjualan $\mathrm{CV}$. Jembatan Lintas Benua relatif masih stabil. Seperti menggunakan strategi pemasaran yang lebih baik, terutama melalui media internet.

Sebuah perusahaan perlu melakukan pengembangan usaha dengan merumuskan suatu formulasi strategi. Menurut Pearce dan Roobinson (2008), formulasi strategi akan mengarahkan para eksekutif dalam mendefinisikan bisnis di mana perusahaan mereka berada, tujuan akhir yang ingin dicapai, dan sarana untuk mencapai tujuan tersebut

\section{METODE}

Kegiatan pengabdian ini difokuskan kepada pengembangan SDM dan pengembangan website untuk pemasaran internasional. Adapun tahapan kegiatan yang dilakukan adalah sebagai berikut:

1. Koordinasi dengan mitra Koordinasi diperlukan guna mengidentifikasi kembali permasalahan-permasalahan yang ada pada mitra serta 
pengumpulan data sebelum kegiatan pengabdian dimulai. Selain mengumpulkan data awal juga dibuat nota kesepakatan-kesepakatan agar program IbPU dapat dijalankan bersama-sama seperti: (a) Komitmen mitra dan Tim Pengabdi dalam mensukseskan pelaksanaan IbPU seperti yang telah direncanakan, (b) Kesepakatan waktu dari pelaksanaan kegiatan-kegiatan yang akan diselenggarakan agar dapat dihadiri oleh Mitra dan Tim Pengabdi.

2. Pelatihan inclass

Pelatihan inclass dilakukan dengan tujuan untuk meningkatkan kualitas SDM kedua mitra. Pelatihan dilakukan selama 2 kali dalam satu tahun. Adapun materi yang diberikan antara lain; wawasan kewirausahaan, manajemen keuangan dan manajemen pemasaran terutama dengan memanfaatkan internet dan media on line.

3. Pemberian Teknologi Tepat Guna

Teknologi tepat guna yang diberikan kepada CV. Jembatan Lintas Benua berupa seperangkat PC komputer dan alamat website baru yang dapat digunakan untuk menunjang pemasaran internasional. Dengan demikian, produksi barangbarang mebel akan semakin meningkat dan meningkatkan perekonomian karyawan.

\section{HASIL DAN PEMBAHASAN}

A. Kesepakatan bersama

Koordinasi-koordinasi telah dila-kukan untuk mematangkan alternative solusi yang ditawarkan mengacu pada kondisi mitra saat itu. Dari hasil koordinasi ini disepakati sebagai berikut :

1. Pembaharuan website CV. Jembatan Lintas Benua dengan membeli domain baru yang lebih kredibel dan meyakinkan.

2. Perlunya pelatihan kepada karyawan CV. Jembatan Lintas Benua mengenai wawasan kewirausahaan, Manajemen keuangan dan pemasaran.

B. Pengambilan bahan dan materi untuk pengisian konten website Pengambilan gambar dilakukan meliputi perekaman logo, profil serta proses produksi mebel. Selain itu pada saat mebel-mebel yang telah jadi akan dikirim kepada pembeli juga dilakukan perekaman baik secara gambar maupun video.

C. Pembuatan website

Pembuatan website ini dilakukan selama kurun waktu tiga bulan. Dalam kegiatan pembuatan website ini melibatkan ahli IT dari Universitas Sebelas Maret. Lamanya pembuatan konten website karena diperlukan koordinasi dan re-cek tentang 
nama website yang akan digunakan, konten/isi website, desain website dan gambargambar yang akan diambil. Pemilihan nama website agak mengalami kesulitan karena ternyata sudah ada nama yang sama digunakan oleh perusahaan lain. Sehingga diputuskan untuk menggunakan nama dalam Bahasa Inggris.

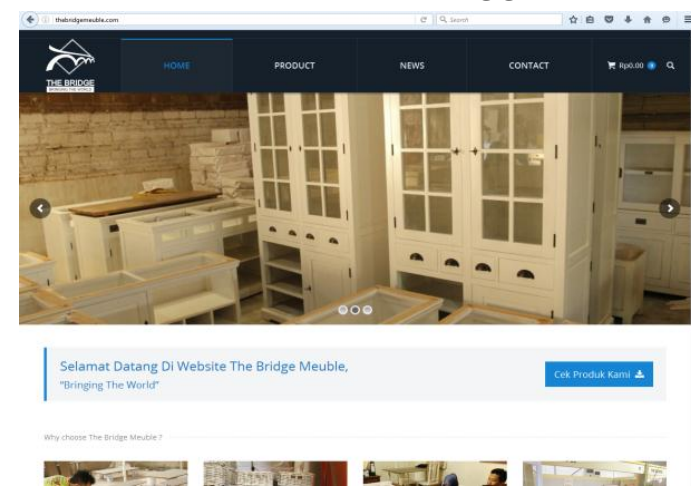

Gambar 1. Tampilan Beranda Website

\section{Penyediaan Teknologi Tepat} Guna

Teknologi Tepat Guna yang diberikan berupa seperangkat komputer yang digunakan sebagai alat untuk memasarkan produk mebel hingga ke skala internasional.

E. Pelatihan Inclass

Pelatihan inclass ini bertujuan untuk melatih mengenai peluang usaha dan manajemen pemasaran. Pelatihan inclass ini dilakukan sebanyak dua kali pada waktu yang berbeda. Dalam pelatihan yang pertama disampaikan materi mengenai peluang usaha dan achievement motivation agar lebih meningkatkan motivasi berprestasi bagi karyawan. Sedangkan pada pelatihan kedua lebih fokus pada pembahasan teknik-teknik jitu pemasaran serta pengelolaan website untuk menunjang pemasaran usaha. Pelatihan dilakukan dengan santai dan dilaksanakan pada hari libur sehingga peserta tidak merasa terbebani antara menyelesaikan pekerjaan dengan mengikuti pelatihan.

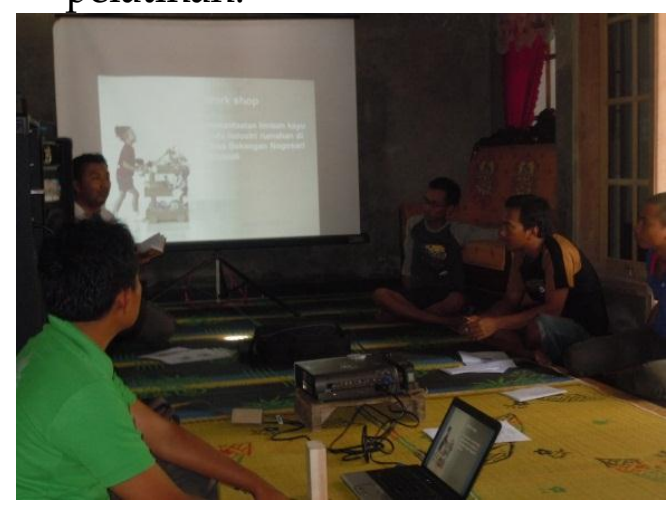

Gambar 2. Pelatihan Inclass

a. Pelatihan Peningkatan Motivasi Kewirausahaan

Pada dasarnya inti dari berhasilnya suatu kegaitan usaha adalah dimilikinya keterampilan dalam mencari peluang usaha. Peluang usaha disini adalah sebuah kesempatan yang bisa di dapatkan oleh seseorang dengan cara mengandalkan suatu potensi dan keahlian yang telah dimiliki oleh orang tersebut dengan cara memanfaatkan waktu dan kondisi yang ada. Kunci keberhasilan menangkap peluang usaha akan diidentifikasikan oleh pengalaman dan pendekatan terhadap faktor manusia, sedang kunci 
keberhasilan lainnya ditentukan oleh teknologi, komunikasi dan informasi.

b. Pelatihan Pemasaran dan Pengelolaan Website

Pelatihan

pemasaran dimaksudkan untuk meningkatkan pengetahuan mitra mengenai bagaimana cara pemasaran dengan baik. Peserta pelatihan dibekali pengetahuan mengenai pene-rapan sistem pemasaran bagi usaha kecil khususnya melalui internet. Triktrik yang disampaikan antara lain bagaimana cara menyebarkan brosur-brosur elektronik pada saat yang tepat serta pada pangsa pasar yang tepat pula, up dating konten website serta pengelolaannya.

\section{F. Evaluasi dan Monitoring}

Evaluasi dan monitoring dilakukan untuk mengetahui keberhasilan kegiatan IbPU ini. Evaluasi dan monitoring meliputi penggunaan website untuk pemasaran. Selama masa ujicoba website, diketahui bahwa fitur-fitur yang disediakan dapat berjalan dengan baik. Bahkan ada satu orang yang menghubungi $\mathrm{CV}$. Jembatan Lintas Benua untuk memesan mebel melalui website.

\section{KESIMPULAN DAN SARAN}

Kesimpulan yang dapat diambil antara lain :

1. Pengabdian dengan metode pelatihan dan pendampingan yang melibatkan peran serta aktif dari industri mitra masih diminati serta dapat mencapai hasil yang telah direncanakan sebelumnya.

2. Pemasaran melalui internet dengan membuat website sudah terbukti efektif dan efisien.

Sedangkan saran yang dapat diberikan kepada industri mitra adalah harus ada yang aktif mengelola website terutama mengunggah produk-produk yang ditawarkan pada jam-jam tertentu secara berulang. Hal ini untuk menunjukkan bahwa aktivitas di website tinggi sehingga konsumen lebih yakin akan kredibilitas perusahaan.

\section{DAFTAR PUSTAKA}

Neraca. (2016). Industri furniture ditaksir tumbuh $10 \%$. www.neraca.co.id/harian/article/ 21131/Industri.Furniture.Ditak sir. Diakses pada 19 Agustus 2016.

Pearce, John A; Robinson, Richard B. (2008). Manajemen strategis: Formulasi, Implementasi, dan Pengendalian. Jakarta: Salemba Empat.

Suseno A., Indriyani R. 2013. Pengelolan dan Pengembangan Usaha Furniture pada UD Ethnic Furniture. J. Agora 1 (3).

Tjoa GEE., Harjanti D. 2013. Pengelolaan Dan Pengembangan Usaha Furniture Pada Cv. Xyz di Sidoarjo. J. Agora 1 (1). 